\title{
Afar Language
}

National Cancer Institute

\section{Source}

National Cancer Institute. Afar Language. NCI Thesaurus. Code C153821.

An Afroasiatic language belonging to the Cushitic branch, spoken by the Afar people inhabiting Djibouti, Eritrea and Ethiopia. 